DOI: https://doi.org/10.24127/ajpm.v9i4.3190

\title{
EFEKTIVITAS PENGGUNAAN LEMBAR KERJA MAHASISWA BERBASIS PROJECT BASED LEARNING (PJBL) TERINTEGRASI ICT
}

\author{
Nurmi $^{1}$, Alfi Yunita ${ }^{2}$, Radhya Yusri $^{3}$, Hafizah Delyana ${ }^{4 *}$ \\ 1,2,3,4* STKIP PGRI Sumatera Barat, Padang, Indonesia \\ ${ }^{*}$ Corresponding author \\ E-mail: $\quad$ olmiinu@yahoo.com ${ }^{1)}$ \\ alfiyunita2683@gmail.com $^{2)}$ \\ radhyayusri01@gmail.com $^{3)}$ \\ $\underline{\text { hafizahdelyana@gmail.com }}^{4 *}$
}

Received 29 October 2020; Received in revised form 03 December 2020; Accepted 21 December 2020

\begin{abstract}
Abstrak
Pemahaman mahasiswa yang kurang terhadap materi, Buku teks yang tidak memadai, serta bahasa buku yang tidak komunikatif sebagai faktor penyebab rendahnya hasil belajar mahasiswa. Tujuan penelitian ini adalah untuk menghasilkan Lembar Kerja Mahasiswa (LKM) berbasis Project Based Learning. erintegrasi Information and Computer Technology/ICT yang efektif. Model penelitian yang digunakan adalah Model Plomp yaitu preliminary research, prototyping phase dan assessment phase. Populasi pada penelitian ini adalah Mahasiswa Program Studi Pendidikan Matematika STKIP PGRI Sumatera Barat. Subjek penelitian diambil secara Purposive Sampling. Instrumen yang digunakan adalah tes berbentuk essay yang terdiri dari soal pre-test dan post-test. Penelitian ini menggunakan metode deskriptif kuantitatif. Desain penelitian ini adalah One Group Pretest-Postest Design. Teknik análisis dari hasil belajar tentang keefektifan LKM menggunakan uji t tipe dua arah. Hasil analisis tes menunjukkan bahwa rata-rata nilai post-test yang diperoleh mahasiswa lebih baik daripada rata-rata nilai pre-test yang diperolehnya. Disimpulkan bahwa penggunaan Lembar Kerja Mahasiswa berbasis Project Based Learning terintegrasi ICT efektif dalam meningkatkan hasil belajar mahasiswa pada mata kuliah Geometri Ruang sehingga efektif digunakan untuk proses pembelajaran. Diharapkan LKM ini dapat dijadikan salah satu sumber belajar yang mampu mengembangkan potensi kemampuan mahasiswa dan meningkatkan hasil belajar mahasiswa.
\end{abstract}

Kata kunci: efektivitas; hasil belajar; ICT; lembar kerja mahasiswa; project based learning.

\begin{abstract}
Lack of students' understanding of the material, inadequate textbooks, and uncommunicative language of books as factors causing low student learning outcomes. The purpose of this research is to produce an effective Project Based Learning Integrated Student Worksheet (LKM) based on Information and Computer Technology. The research model used is the Plomp Model, namely preliminary research, prototyping phase and assessment phase. The population in this study were students of the Mathematics Education Study Program of STKIP PGRI Sumatera Barat. The research subjects were taken by purposive sampling. The instrument used was an essay test consisting of pre-test and post-test questions. This research uses descriptive quantitative method. The design of this research is One Group PretestPostest Design. The analysis technique of the learning outcomes about the effectiveness of the worksheet uses a two-way type $t$ test. The results of the test analysis showed that the average post-test score obtained by students was better than the average pre-test score obtained by the students. It was concluded that the use of ICT-integrated Project Based Learning-based Student Worksheets was effective in improving student learning outcomes in the Spatial Geometry course so that it was effectively used for the learning process. It is hoped that this worksheet can be used as a learning resource that is able to develop the potential of students' abilities and improve student learning outcomes.
\end{abstract}

Keywords: effectiveness; ICT; learning outcome; project based learning; student worksheets.

This is an open access article under the Creative Commons Attribution 4.0 International License 
DOI: https://doi.org/10.24127/ajpm.v9i4.3190

\section{PENDAHULUAN}

Kehidupan era globalisasi kedepan sarat dengan problema dan tantangan yang sangat komplek, pendidikan harus bisa menyiapkan generasi yang mampu menjawab tantangan dan problema yang dihadapi, yakni menyiapkan generasi yang berkepribadian dan mampu memecahkan berbagai masalah yang dihadapi. Proses pembelajaran pada satuan pendidikan diselenggarakan harus interaktif, inspiratif, menyenangkan dan menantang, memotivasi peserta didik untuk berpartisipasi aktif serta memberikan ruang yang cukup untuk prakarsa, kreatifitas dan kemandirian sesuai dengan bakat, minat dan perkembangan fisik dan psikologis peserta didik (Direktorat Pembelajaran dan Kemahasiswaan, 2014).

Proses pembelajaran yang banyak dipraktekkan sekarang ini sebagian besar berbentuk penyampaian secara tatap muka (lecturing), atau penyampaian secara searah, bahkan materi pembelajaran umumnya disusun tidak mengikuti taksonomi dimensi pengetahuan yang akan dicapai dan dimensi proses kognitif secara benar, (Direktorat Pembelajaran dan Kemahasiswaan, 2014). Akibatnya, pada saat proses perkuliahan berlangsung mahasiswa kesulitan untuk mengikuti atau menangkap makna esensi materi pembelajaran.

Berdasarkan hasil observasi dan analisis yang dilakukan selama di lapangan diperoleh informasi bahwa buku teks dan bahan ajar yang tersedia di kampus tidak memadai. Penyajian materi yang terdapat dalam buku teks kurang komunikatif dan representatif sehingga sulit dipahami oleh mahasiswa. Ketidakteraturan materi dalam buku teks menyebabkan kesinambungan materi menjadi ter- ganggu. Hal ini tentu dapat menghambat terciptanya proses perkuliahan yang kondusif dan efektif. Selain itu pemahaman mahasiswa terhadap konsep yang ada pada buku teks masih kurang, terutama pada konsep matematika yang bersifat abstrak. Karena mata kuliah ini membutuhkan kemampuan visualisasi mahasiswa yang relatif tinggi. Oleh karena itu, dengan adanya bahan ajar yang mengintegrasikan pembelajaran dengan teknologi informasi dan komunikasi (Information and Computer Technology, akan tercipta pembelajaran yang kondusif, efektif serta mampu mengembangkan potensi kemampuan mahasiswa, (Nurseto, 2012). Pembelajaran matematika yang terintegrasi ICT merupakan pembelajaran yang dilakukan dengan memanfaatkan teknologi komputer sebagai sarana dalam menunjang kelancaran proses pembelajaran (van der Akker et al., 1992). Sehingga, seorang dosen harus berupaya untuk terus berinovasi dan melakukan pembaharuan dengan menciptakan pembelajaran yang mampu mengembangkan potensi kemampuan mahasiswa (Direktorat Pembelajaran dan Kemahasiswaan, 2014).

Pembelajaran berbasis proyek adalah Suatu metode pengajaran sistematis yang melibatkan para siswa dalam mempelajari pengetahuan dan keterampilan melalui proses yang tersruktur, pengalaman nyata dan teliti yang dirancang untuk menghasilkan produk (Ravitz, 2008). Inti project based learning yaitu menghubungkan pengalaman mahasiswa dengan kehidupan untuk menumbuhkan pemikiran kritis mahasiswa (Efstratia, 2014). Dalam hal ini, dilakukan penelitian untuk mengetahui efektivitas penggunaan Lembar Kerja Mahasiswa Berbasis Project Based Learning 
DOI: https://doi.org/10.24127/ajpm.v9i4.3190

terintegrasi ICT pada Mata Kuliah Geometri Ruang.

\section{METODE PENELITIAN}

Penelitian ini menggunakan metode deskriptif kuantitatif. Desain penelitian ini adalah One Group Pretest-Postest Design, yang mana dalam penelitian eksperimen model ini digambarkan pada Gambar 2.

$$
\mathrm{O}_{1} \times \mathrm{O}_{2}
$$

Gambar 2. Desain Penelitian

Keterangan:

$$
\begin{aligned}
& \mathrm{X}=\begin{array}{c}
\text { (Treatment) perlakuan yang } \\
\text { diberikan }
\end{array} \\
& \mathrm{O} 1= \text { Nilai Pretest } \\
& \text { perlakuan) }
\end{aligned}
$$

Tempat Penelitian ini dilaksanakan pada kelas Angkatan 2017 di Program Studi Pendidikan Matematika yang mengambil mata kuliah Geometri Ruang. Waktu Penelitian ini dilaksanakan semester genap Tahun Ajaran 2018/2019. Teknik pengambilan sampel menggunakan Purporsive Sampling. Sampel diambil menggunakan teknik purposive dengan pertimbangan atau kriteria tertentu. Variabel dependen dalam penelitian ini adalah hasil belajar mahasiswa pada mata kuliah Geometri Ruang. Variabel independen dalam penelitian ini adalah penggunaan Lembar Kerja Mahasiswa (LKM) Berbasis Project Based Learning terintegrasi ICT.

Instrumen penelitian yang digunakan dalam penelitian ini adalah tes untuk mengukur efektivitas pengggunaan media LKM terhadap hasil belajar matematika mahasiswa. Teknik analisis data dari hasil belajar tentang keefektifan LKM menggunakan uji t tipe dua arah pada rumus (1), dalam (Rijal \& Sofiarini, 2019):

$$
t=\frac{M d}{\sqrt{\frac{\sum\left(x^{2} d\right)}{N(N-1)}}}
$$

Hasil pengujian menolak $H_{0}$ dengan kriteria, jika $t_{H i t}<-t_{\alpha}$ or $t_{H i t}>t_{\alpha}$, dengan level signifikansi 0.05 .

\section{HASIL DAN PEMBAHASAN}

Keefektifan Lembar Kerja Mahasiswa (LKM) berbasis project based learning terintegrasi Information and Computer Technology /ICT digunakan untuk mendorong terciptanya pembelajaran mandiri, interaktif, inspiratif, menantang, dan memotivasi mahasiswadalam proses pembelajaran serta menjadikan pembelajaran lebih efektif dan efisien. Sehingga berpengaruh terhadap hasil belajar yang diperoleh mahasiswa dalam proses pembelajaran. Hal itu dapat dilihat berdasarkan hasil pre-test dan post-test yang diperolehnya.

Pre-test dilakukan untuk mengetahui tingkat pemahaman mahasiswa tentang materi yang dipelajaris sebelum menggunakan LKM berbasis project based learning terintegrasi ICT. Di akhir diberikan post-test untuk mengetahui tingkat kemampuan mahasiswa dengan adanya LKM berbasis project based learning terintegrasi ICT.Soaltes yang diberikan sebelumnya telah divalidasi oleh dosen pengajar mata kuliah Geometri Ruang. Berikut hasil pre-test dan post-test mahasiswa seperti terlihat pada Tabel 1 .

\begin{tabular}{ccccc}
\multicolumn{6}{c}{ Tabel 1. Hasil pre-test dan post-test } \\
\hline $\begin{array}{c}\text { Type of } \\
\text { test }\end{array}$ & Mean & $\mathrm{S}$ & $\mathbf{X}_{\max }$ & $\mathbf{X}_{\min }$ \\
\hline Pre-test & 51,52 & 40,09 & 79 & 25 \\
Post-test & 73,95 & 61,3 & 86 & 60 \\
\hline
\end{tabular}


DOI: https://doi.org/10.24127/ajpm.v9i4.3190

Tabel 1 menunjukkan bahwa ratarata nilai post-test mahasiswa yang diberi pembelajaran dengan menggunakan LKM berbasis project based learning terintegrasi ICT lebih tinggi dibandingkan nilai pre-test mahasiswa yang diberi pembelajaran tanpa menggunakan LKM berbasis project based learning terintegrasi ICT.

Perhitungan yang dilakukan dengan menggunakan uji $t$, diperoleh nilai $t_{\text {hitung }}=5,12$ dengan $\alpha=0,05$. Sedangkan $t_{\text {tabel }}=1,68$. Karena nilai $t_{\text {hitung }}>t_{\text {tabel }}$, maka $\mathrm{H}_{0}$ ditolak. Jadi dapat disimpulkan bahwa rata-rata hasil belajar mahasiswa dengan menggunakan LKM berbasis project based learning terintegrasi ICT lebih baik daripada rata-rata hasil belajar mahasiswa sebelum menggunakan LKM berbasis project based learning terintegrasi $I C T$.

Berdasarkan hasil penelitian ternyata penggunaan LKM berbasis project based learning terintegrasi ICT cukup efektif dalam meningkatkan hasil belajar mahasiswa. Peningkatan hasil belajar yang diperoleh mahasiswa terjadi karena mahasiswa lebih mudah memahami LKM yang dikembangkan. LKM disajikan dalam bentuk yang menarik, menantang, mudah dimengerti dan jelas karena dikembangkan berdasarkan tahapan Project Based Learning. Hasil jawaban diuji melalui berbagai software untuk mendapatkan pemecahan masalahyang diinginkan. Informasi tentang materi pembelajaran juga mudah dimengerti karena melibatkan berbagai banyak indera terutama telinga dan mata untuk menyerap informasi tersebut, sehingga memungkinkan mahasiswa untuk berpikir kritis, kreatif dalam mencari informasi dan lebih termotivasi dalam proses pembelajaran. Permasalahan yang ada dalam LKM disajikan dalam masalah nyata yang mampu membuat mahasiswa aktif menggali sendiri konsep materi yang dipelajari dengan mengikuti langkah-langkah yang ada pada LKM. Langkah-langkah yang termuat dalam LKM berbasis Project Based Learning adalah: a. Penentuan Pertanyaan Mendasar (Start With the Essential Question). b. Mendesain Perencanaan Proyek (design a Plan for the Project) c. Menyusun Jadwal (Create a Schedule). d. Memonitor peserta didik dan kemajuan proyek (Monitor the Students and the Progress of the Project). e. Menguji Hasil (Assess the Outcome). f. Mengevaluasi Pengalaman (Evaluate the Experience). Peran dosen dalam proses pembelajaran dengan menggunakan LKM berbasis Project Based Learning terintegrasi ICT lebih difokuskan sebagai fasilitator, sementara mahasiswa yang lebih aktif dalam pembelajaran. sehingga tingkat pemahaman mahasiswa terhadap materi lebih baik.

Keunggulan LKM yang dikembangkan dibandingkan dengan LKM yang lain pada umumnya adalah LKM berbasis project based learning ini terintegrasi dengan ICT yaitu pengintegrasian LKM dengan menggunakan berbagai software pembelajaran seperti software wingeom, geoGebra, Autograph, dst yang memudahkan mahasiswa dalam memahami materi dan dapat memotivasi mereka dalam mengerjakan tugas proyek yang diberikan (Zouganeli et al., 2014).

Pengintegrasian software dalam LKM berbasis project based learning juga dilengkapi dengan petunjukpetunjuk untuk menentukan solusi dari permasalahan yang diberikan. Pemberian contoh soal dan latihan yang bervariasi juga akan membantu mahasiswa dalam merefleksi sejauh 
mana mereka menguasai materi yang sudah dipelajari dalam proses pembelajaran yang bertujuan untuk menggali pengetahuan dan pengalaman mereka dari kegiatan yang sudah dikerjakan.

Efektivitas yang juga mendukung bahwa penggunaan LKM dapat meningkatkan hasil belajar dan menumbuhkembangkan potensi kemampuan mahasiswa dalam proses pembelajaran adalah karena kegiatan yang ada dalam LKM melibatkan mahasiswa dalam mengerjakan atau menyelesaikan permasalahan apalagi dengan pengintegrasian LKM dengan ICT. Pembelajaran dengan penggunaan LKM dapat melatih mahasiswa untuk memberikan argumen, melakukan evaluasi serta memutuskan dan menyelesaikan permasalahan yang diberikan. LKM dapat memberikan peluang kepada mahasiswa untuk menumbuhkan keterampilan berpikir kritis, kreatif dan dapat meningkatkan penguasaan konsep mahasiswa. Dengan adanya bahan ajar berupa LKM berbasis project based learning terintegrasi ICT diharapkan dapat melatih kemandirian mahasiswa, berani mengungkapkan pendapat dan belajar mengembangkan logika berpikir serta membangun kerjasama yang akan memunculkan kreatifitas, berpikir logis dan sistematis mahasiswa, sehingga proses pembelajaran yang terjadi akan bermakna (Kortam et al., 2018).

Penggunaan Lembar Kerja Mahasiswa berbasis project based learning dapat mendorong terciptanya pembelajaran mandiri, interaktif, inspiratif, menantang, dan memotivasi mahasiswa dalam proses pembelajaran serta akan menjadikan pembelajaran lebih efektif dan efisien (Sumarni et al., 2016). LKM berbasis project based learning terintegrasi ICT dapat membuat mahasiswa menemukan konsep sendiri sesuai dengan pengetahuan dan keterampilan yang dimilikinya(Sumarni et al., 2016). LKM membantu peserta didik untuk menambah informasi tentang konsep yang dipelajari melalui kegiatan belajar secara sitematis dan mampu meningkatkan kreativitas dan berfikir kritis peserta didik (Anazifa \& Djukri, 2017).

Bahan ajar merupakan salah satu media pembelajaran yang dapat membantu mahasiswa dalam memahami materi(Febriana et al., 2017). Adanya pembelajaran berbasis proyek dapat meningkatkan kemampuan kognitif maupun keterampilan peserta didik dalam proses pembelajaran (Mukama, 2010), dapat meningkatkan motivasi dan antusiasme peserta didik dalam mengikuti proses pembelajaran (Zouganeli et al., 2014) serta dapat mengembangkan ide-ide kreatif dan keterampilan peserta didik dalam proses pembelajaran(Sart, 2014). Penggunaan bahan ajar berbasis project based learning dapat membuat peserta didik terlibat aktif dan bersemangat dalam mengikuti proses pembelajaran (Habók \& Nagy, 2016). Sebagian besar memiliki sikap positif dengan adanya bahan ajar berbasis project based learning (Chu et al., 2017). Pembelajaran berbasis proyek menjadikan pembelajaran menjadi bermakna (García, 2016). Rata-rata hasil belajar mahasiswa dengan menggunakan bahan ajar berbasis project based learning meningkat secara signifikan (Nurmi, 2018).

Suatu proses pengajaran bisa dikatakan berhasil apabila pembelajaran tersebut bisa memotivasi mahasiswa dan membangkitkan proses pembelajaran yang efektif (Afriana et al., 2016). Hasil belajar merupakan 
hasil dari suatu interaksi tindakan belajar dan tindakan mengajar. Hasil belajar digunakan dosen untuk dijadikan ukuran atau kriteria dalam mencapai suatu tujuan pendidikan.

Hasil penelitian ini juga didukung oleh hasil penelitian sebelumnya yang menyatakan bahwa ICT mempunyai manfaat yang sangat luar biasa untuk mendukug proses pembelajaran yaitu mahasiswa dapat terlibat aktif karena ada proses pembelajaran yang menarik dan bermakna, mahasiswa dapat menggabungkan ide-ide baru kedalam pengetahuan yang telah dimiliki sebelumnya untuk memahami makna atau keingintahuan yang selama ini ada dalam pikirannya. Sehingga memungkinkan mahasiswa saling bekerjasama dalam kelompok, dapat secara aktif dan antusias untuk mencapai tujuan yang diinginkan, mengarahkan perhatian mahasiswa dan mendorong minat mahasiswa dalam proses pembelajaran (Blumenfeld et al., 1991).

Di samping itu, dari hasil penelitian lainnya terlihat bahwa pembelajaran dengan penggunaan LKM memberikan kemudahan dalam mengajar dan memudahkan mahasiswa dalam memahami isi materi sehingga mampu meningkatkan pengetahuan dan pengalamannya (Wurdinger \& Qureshi, 2015). Daya ingat mahasiswa dalam proses pembelajaran meningkat akibat proses pembelajaran dengan menggunakan LKM. Jadi LKM yang dijadikan sebagai media dan sumber belajar lebih efektif meningkatkan hasil belajar mahasiswa. Sehingga, dapat dikatakan bahwa penggunaan LKM berbasis project based learning terintegrasi ICT adalah sebagai umpan balik bagi mahasiswa dan dosen. Bagi dosen LKM dapat digunakan untuk mempermudah dalam memberikan atau menjelaskan materi sedangkan untuk mahasiswa sebagai alat untuk belajar mandiri (Matsun, 2015).

\section{KESIMPULAN DAN SARAN}

Hasil analisis menunjukkan bahwa penggunaan Lembar Kerja Mahasiswa berbasis Project Based Learning terintegrasi Information and Computer Technology efektif dalam meningkatkan hasil belajar mahasiswa pada mata kuliah Geometri Ruang sehingga efektif digunakan dalam proses pembelajaran. Bahan ajar memiliki peran penting untuk menunjang proses pembelajaran. Jika pembelajaran yang diharapkan mampu mengembangkan potensi.

Oleh karena itu, diharapkan peneliti selanjutnya dapat melakukan pengembangan Modul Geometri Ruang berbasis Project Based Learning yang bisa meningkatkan hasil belajar mahasiswa sehingga pembelajaran menjadi lebih menarik dan tidak membosankan.

\section{DAFTAR PUSTAKA}

Afriana, J., Permanasari, A., \& Fitriani, A. (2016). Project based learning integrated to stem to enhance elementary school's students scientific literacy. Jurnal Pendidikan IPA Indonesia, 5(2), 261-267.

https://doi.org/10.15294/jpii.v5i2.5 493

Anazifa, R. D., \& Djukri. (2017). Project- based learning and problem- based learning: Are they effective to improve student's thinking skills? Jurnal Pendidikan IPA Indonesia, 6(2), 346-355. https://doi.org/10.15294/jpii.v6i2.1 1100 
Blumenfeld, P. C., Soloway, E., Marx, R. W., Krajcik, J. S., Guzdial, M., \& Palincsar, A. (1991). Motivating Project-Based Learning: Sustaining the Doing, Supporting the Learning. In Educational Psychologist (Vol. 26, Issues 3-4, pp. 369-398). https://doi.org/10.1080/00461520.1 991.9653139

Chu, S. K. W., Zhang, Y., Chen, K., Chan, C. K., Lee, C. W. Y., Zou, E., \& Lau, W. (2017). The effectiveness of wikis for projectbased learning in different disciplines in higher education. Internet and Higher Education, 33, 49-60.

https://doi.org/10.1016/j.iheduc.20 17.01.005

Direktorat Pembelajaran dan Kemahasiswaan. (2014). Buku Kurikulum Pendidikan Tinggi. 193.

Efstratia, D. (2014). Experiential Education through Project Based Learning. Procedia - Social and Behavioral Sciences, 152, 12561260.

https://doi.org/10.1016/j.sbspro.20 14.09.362

Febriana, R., Haryono, Y., \& Yusri, R. (2017). Effectiveness of Discovery Learning-Based Transformation Geometry Module. Journal of Physics: Conference Series, 895(1).

https://doi.org/10.1088/17426596/895/1/012003

García, C. (2016). Project-based Learning in Virtual Groups Collaboration and Learning Outcomes in a Virtual Training Course for Teachers. Procedia Social and Behavioral Sciences, 228(June), 100-105. https://doi.org/10.1016/j.sbspro.2016 .07 .015
Habók, A., \& Nagy, J. (2016). Inservice teachers' perceptions of project-based learning. SpringerPlus, 5(1), 1-14. https://doi.org/10.1186/s40064016-1725-4

Kortam, N., Basheer, A., Hofstein, A., \& Hugerat, M. (2018). How Project-Based Learning promotes 7 th grade students ' motivation and attitudes towards studying biology. Action Research and Innovation in Science Education, 1(2)(August), 9-17.

Matsun. (2015). Pengembangan Media Pembelajaran Elektronika Lanjutan pada Materi Gerbang Logika Menggunakan Adobe Flash. Jurnal Pendidikan Informatika Dan Sains, 4(1), 99-111.

Mukama, E. (2010). Strategizing computer-supported collaborative learning toward knowledge building. International Journal of Educational Research, 49(1), 1-9. https://doi.org/10.1016/j.ijer.2010. 05.001

Nurmi. (2018). Effect Of Student Worksheets Based On Projects That Integrate Information Technology On Problem-Solving Achievement. European Journal of Education Studies. 95-102. https://doi.org/10.5281/zenodo.148 9188

Nurseto, T. (2012). Membuat Media Pembelajaran yang Menarik. Jurnal Ekonomi Dan Pendidikan, 8(1), 19-35. https://doi.org/10.21831/jep.v8i1.7 06

Ravitz, J. (2008). Project Based Learning as a Catalyst in Reforming High Schools. American Educational Research Association, 1-14. 
DOI: https://doi.org/10.24127/ajpm.v9i4.3190

Rijal, A., \& Sofiarini, A. (2019). Pengembangan E-Learning Mata Kuliah Pembelajaran Matematika Sd Berbasis Aplikasi Moodle Di Pgsd. Jurnal Basicedu, 3(4), 20712082.

https://doi.org/10.31004/basicedu.v $3 \mathrm{i} 4.266$

Sart, G. (2014). The Effects of the Development of Metacognition on Project-based Learning. Procedia Social and Behavioral Sciences, 152, 131-136. https://doi.org/10.1016/j.sbspro.20 14.09.169

Sumarni, W., Wardani, S., Sudarmin, S., \& Gupitasari, D. N. (2016). Project based learning (PBL) to improve psychomotoric skills: A classroom action research. Jurnal Pendidikan IPA Indonesia, 5(2), 157-163.

https://doi.org/10.15294/jpii.v5i2.4 402 van der Akker, J., Keursten, P., \& Plomp, T. (1992). The integration of computer use in education. International Journal of Educational Research, 17(1), 6576. https://doi.org/10.1016/08830355(92)90042-5

Wurdinger, S., \& Qureshi, M. (2015). Enhancing College Students' Life Skills through Project Based Learning. Innovative Higher Education, 40(3), 279-286. https://doi.org/10.1007/s10755014-9314-3

Zouganeli, E., Tyssø, V., Feng, B., Arnesen, K., \& Kapetanovic, N. (2014). Project-based learning in programming classes - The effect of open project scope on student motivation and learning outcome. IFAC Proceedings Volumes (IFAC-PapersOnline), 19, 1223212236.

https://doi.org/10.3182/20140824-

6-za-1003.02412 